\title{
Problems and prospects of cottage construction in Russia
}

\author{
Vitaly Kasyanov ${ }^{1 *}$, Olga Landysheva ${ }^{1 *}$ \\ ${ }^{1}$ Moscow State University of Civil Engineering, 129337, 26, Yaroslavskoye Shosse, Moscow, Russia
}

\begin{abstract}
Sustainable development of building complex in suburban territories and reorientation of building construction to low-rise construction is the actual direction of the construction industry. Countryside real estate in the cottage settlements is a new popular housing format in Russia. It is already an established market in Moscow and St. Petersburg: it has clear rules, criteria, participants, fixed offer and demand. The article deals with the sustainable development of suburban territories. The article is carried out qualitative and quantitative assessment of cottage construction industry in the Moscow region, problems of development of cottage construction as part of sustainable development for cities and suburban territories. The article focuses on the legal status of the cottage and the cottage settlements, it proposes some elements of cottages classification. The article describes the possible prospects of cottage construction development as one of the main directions of low-rise construction development. The presented results in the article can serve for further development and improvement of methods and tools, and also for researches materials that conducted in this area.
\end{abstract}

\section{Introduction}

Sustainable development of cities and suburban territories is aimed at the preservation and modernization of urban environment to improve people's standard and quality of living. Architectural and planning concept is relevant for suburban territories development. It includes:

- preservation and reconstruction of the architectural and landscape heritage;

- implementation of a clear and rational territorial zoning;

- achievement more rational and environmentally friendly planning and functional organization of suburban territories.

World trends in residential development focused on the formation of a healthy, clean and comfortable life environment of population. Modern regional planning is destined for the priority of suburban low-rise construction in ecologically clean zones.

Modernization of mass residential development is one of the main directions in the sustainable development of cities and suburban territories. The quality of residential development is a complex concept, which includes the concept of rationality, functionality, comfort, economy, security, solidity.

According to numerous sociological survey most Russians want to live "closer to the ground" - in cottages or in areas of low-rise construction [1]. And this is understandable: unlike a city apartment

* corresponding e-mail LandyshevaOE@mgsu.ru 
own house is conceptually new quality of life. A priority for the population is the comfort of living, but not volume of commissioned lodging space.

Data of Federal State Statistics Service of Russian Federation (Rosstat) shows the general trend of the Russians preferences: the share of commissioning of individual houses in the total commissioned lodging space has increased annually over the past 10 years (table. 1) [2].

Table 1. Dynamics of commissioning of individual houses

\begin{tabular}{|c|c|c|c|c|c|c|c|c|c|c|}
\hline & 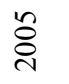 & 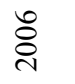 & $\hat{\check{d}}$ & 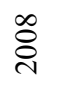 & \&े & 웅 & $\bar{\Xi}$ & $\stackrel{\text { ㄱ }}{\circ}$ & $\stackrel{m}{\circ}$ & $\stackrel{+}{\stackrel{N}{2}}$ \\
\hline $\begin{array}{l}\text { Commissioning of } \\
\text { individual houses, } \\
\text { thousand }\end{array}$ & సे & $\tilde{q}$ & $\begin{array}{l}0 \\
+ \\
\infty\end{array}$ & ث̊ & 赵 & $\begin{array}{l}0 \\
\infty \\
\infty\end{array}$ & $\hat{a}$ & n & 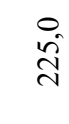 & $\begin{array}{l}n \\
\stackrel{0}{0} \\
\stackrel{0}{2}\end{array}$ \\
\hline $\begin{array}{l}\% \text { to previous } \\
\text { year }\end{array}$ & के & $\stackrel{\vec{m}}{=}$ & $\tilde{m}$ & $\begin{array}{l}0 \\
\dot{0}\end{array}$ & ?n & $\stackrel{+}{\infty}$ & 妾 & : & $\overrightarrow{0}$ & $\stackrel{\overbrace{}}{\emptyset}$ \\
\hline $\begin{array}{l}\text { Share in the total } \\
\text { area of } \\
\text { commissioned } \\
\text { lodging space, } \%\end{array}$ & ֶै & مे & $\stackrel{\circ}{\tilde{f}}$ & $\hat{\tilde{f}}$ & $\stackrel{\vec{f}}{\sigma}$ & $\hat{\tilde{g}}$ & $\stackrel{0}{\tilde{F}}$ & $\stackrel{\sim}{\tilde{f}}$ & $\tilde{m}$ & 하 \\
\hline
\end{tabular}

The last decade of cottage construction is successfully developing in the suburban territories of large cities in Russia [3].

The number of private houses in the informal settlements is much more than in organized cottage settlements. This trend is caused by the fact of organized cottage settlements mainly belongs to the premium and business class residential property segments (table. 2).

An analysis of the market of cottage settlements in Moscow region was carried out. More than 20 cottage settlements located in the central region of Russia were considered. For the analysis it was used the sources of information and data of Rosstat, print advertising, media, analytical and scientific articles, Internet.

The criterions of estimation for cottage settlements were average cost, location, distance from a city center, site plot, environmental setting, infrastructure development.

The assumed scheme of classification is presented in table. 2 .

Table 2. Classification of cottage settlement

\begin{tabular}{|c|c|c|c|}
\hline $\begin{array}{c}\text { Criterion of } \\
\text { estimation }\end{array}$ & Premium class segment & $\begin{array}{c}\text { Business class } \\
\text { segment }\end{array}$ & Economy-class segment \\
\hline Average cost & $17-30$ million rubles & $8-20$ million rubles & $5-7$ million rubles. \\
\hline Locaton & $\begin{array}{c}\text { Eclogically clean and } \\
\text { picturesque area, } \\
\text { located close to the } \\
\text { forest and water bodies }\end{array}$ & $\begin{array}{c}\text { Ecologically clean } \\
\text { and good natural area }\end{array}$ & Propitious area \\
\hline $\begin{array}{c}\text { Distance from a } \\
\text { city center }\end{array}$ & $\begin{array}{c}\text { Up to } 30 \mathrm{~km} \text {. Easy } \\
\text { transport accessibility to } \\
\text { a center city }\end{array}$ & Up to $30 \mathrm{~km}$. & Up to $50 \mathrm{~km}$. \\
\hline
\end{tabular}




\begin{tabular}{|c|c|c|c|}
\hline $\begin{array}{c}\text { Architectural } \\
\text { style }\end{array}$ & $\begin{array}{c}\text { Original architecture, } \\
\text { landscape design }\end{array}$ & $\begin{array}{c}\text { Modern } \\
\text { architecture }\end{array}$ & $\begin{array}{c}\text { Absent or in the } \\
\text { separate elements }\end{array}$ \\
\hline Infrastructure & $\begin{array}{c}\text { Secured area, access } \\
\text { mode, } \\
\text { facilities of the social } \\
\text { infrastructure and } \\
\text { services sector }\end{array}$ & $\begin{array}{c}\text { Facilities of the social } \\
\text { infrastructure and } \\
\text { services sector }\end{array}$ & $\begin{array}{c}\text { Children's and sports } \\
\text { playgrounds, shop. } \\
\text { Infrastructure is } \\
\text { primarily outside the } \\
\text { settelments }\end{array}$ \\
\hline
\end{tabular}

The analysis identified major criterion of estimation for cottage settlements.

Chaotic uncontrolled construction in suburban territories is a serious problem for the city. Chaotic suburban territories development damages not the city image, but also the environmental situation (Fig. 1).
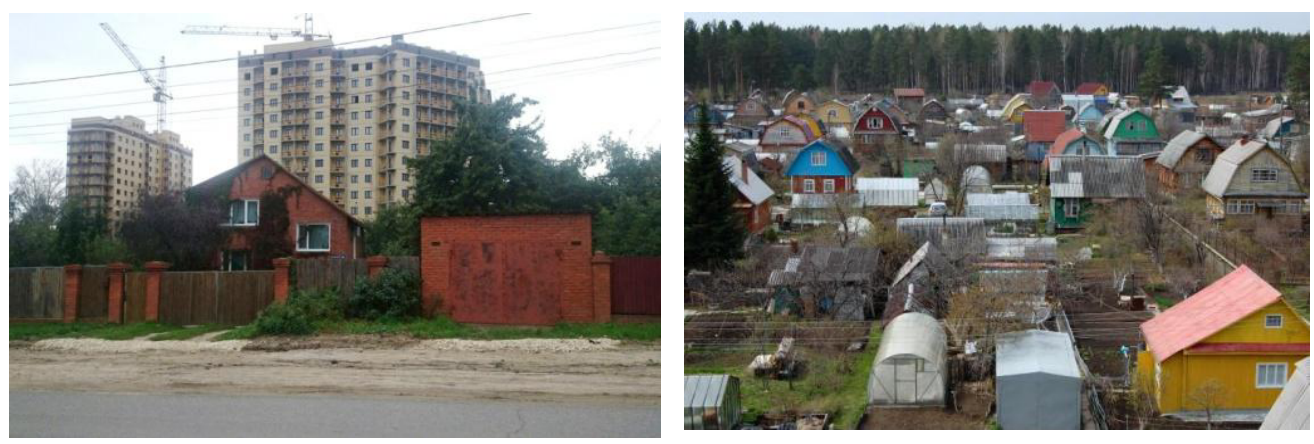

Fig. 1. Chaotic uncontrolled construction in suburban territories/ private sector of suburban territories

The private sector of suburban territories is a special area that requires centralized planning and building development.

As part of the sustainable development of construction complex houses in organized cottage settlements have to be made in the same architectural style, harmoniously fit into the surrounding landscape, avoiding confrontation with nature.

It is necessary to create and implement new specific conditions for private construction of suburban territories.

High cost of private houses in suburban territories is the most important factor hinder the wide development of cottage construction, especially in economy-class segment. Also the significant obstacles of cottage construction are:

- high competitiveness of high-rise construction companies [4];

- difficulties with allocation of land plots for the low-rise construction development;

- high cost of engineering infrastructure.

It should be noted that the legal status of "cottage" is not registered anywhere in the Russian legislation, as well as the concept of "cottage settlements", although there are numerous cottage settlements of different classes around the major cities.

However, all of people understand what is "cottage" intuitively. It is one, two or three-storey building designed for year-round living and supplied with necessary engineering services and sanitized house territory. The two important characteristics of cottage are the modern architecture of the façade and needs to be built in the organized cottage settlements (Fig. 2). 

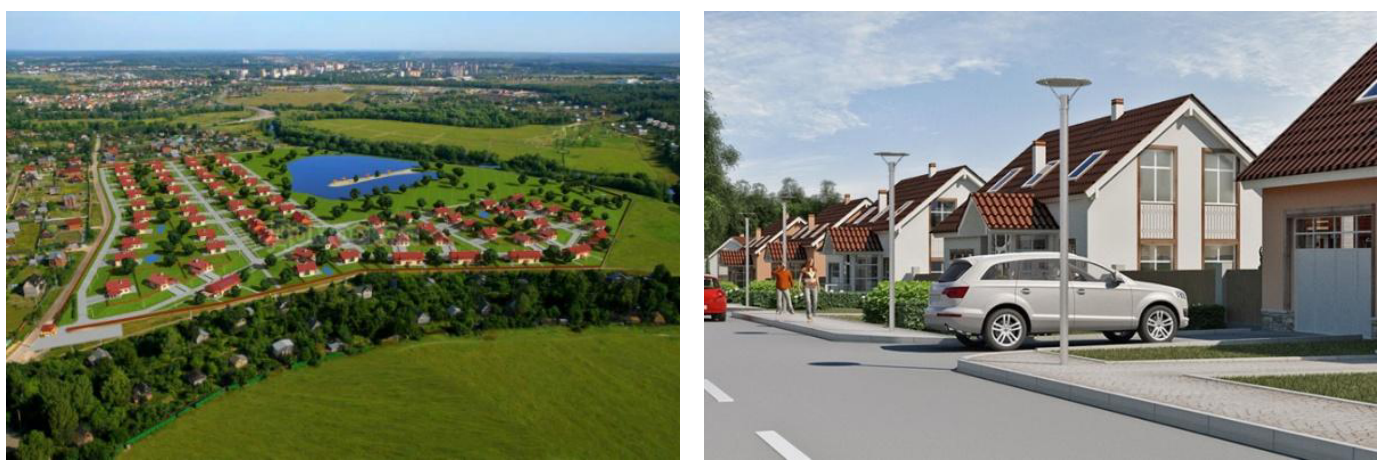

Fig. 2. Cottage settlements «Zarechny», Istra district.

Due to the development of cottage construction it may to solve the following problems:

1. Increase the proportion of square meters per capita.

2. Costs reduction for cottage in suburban territories because of the state programs for development of low-rise construction.

3. Improving the quality of life for people. It will have a positive impact on the demographic processes in the country.

The mentality of Russian citizens is gradually approaching to European standards of comfort living [4]. Living comfort level determined by such factors as space-planning decisions, sanitary norms, reliability, safety and efficiency of power supply, the level of automation of engineering systems and others [5].

\section{Conclusion}

As part of the sustainable development in the suburban territories, the strategic goal for building complex modernization should be the creation of social environmental residential development, material and spatial conditions to ensure environmental safety and quality of living [6- 8]. For planning the building complex modernization in suburban territories consideration must be given to the priority of the interests of people and the long-term interests of society.

From the results it is concluded that the dominance of the construction industry is reorientation of building construction to low-rise construction.

It may be stated that the analysis data prove the necessity to develop and build new private housing that meets the modern requirements for living comfort.

\section{References}

1. I.V. Malyshev, Dissertation abstract, 15-17 (2011)

2. Rosstat, Statistical book on the housing construction in the Russian Federation (2014)

3. A.S. Ermakov, Science and education in modern society, 33-34 (2015)

4. A.S. Ermakov, O.E. Landysheva, Vestnik of Donbas National Academy of Civil Engineering and Architecture 3 (113), 22-24 (2015)

5. V.F. Kasyanov, Publisher of Building universities Association, 224 (2015)

6. V.S. Kazeikin, Baronin S.A, A.G. Chernykh, A.N Androsov, Problematic aspects of the development of low-rise housing construction in Russia, 17-20 (2011)

7. V.F. Kasyanov, B.S. Strigin, Natural and Technical Sciences 9-10 (77), 468-470 (2014)

8. V.F. Kasyanov, N.A. Tabakov, Scientific Review 2, 159-165 (2012) 